\title{
Concept of the Decision-Making Model for Establishment of Dry Port on The Sample of Rijeka Seaport
}

\section{Koncept modela odlučivanja o uspostavi suhe luke na primjeru morske luke Rijeka}

\begin{tabular}{|l|l|l}
$\begin{array}{l}\text { Ivica Lovrić } \\
\text { City of Zagreb } \\
\text { E-mail: ivica.lovric@zagreb.hr }\end{array}$ & $\begin{array}{l}\text { Dajana Bartulović } \\
\text { Institute of Traffic and Communications } \\
\text { Zagreb } \\
\text { E-mail: ipv@ipv-zg.hr }\end{array}$ & $\begin{array}{l}\text { Sanja Steiner } \\
\text { Croatian Academy of Sciences and Arts } \\
\text { Zagreb } \\
\text { E-mail: ssteiner@hazu.hr }\end{array}$
\end{tabular}

\author{
DOI 10.17818/NM/2020/3.7 \\ UDK 656.073 .235 \\ 656.615(497.5 Rijeka) \\ Review / Pregledni rad \\ Paper accepted / Rukopis primljen: 21. 5. 2020
}

\begin{abstract}
Summary
Nowadays, seaports face many problems. One of the major problems is the increase in container traffic, and due to this there are problems such as the lack of space at the seaport terminals, and the congestion on routes serving those terminals, i.e. increase of bottlenecks in land transport systems serving the seaports. For some seaports, the weakest links in their transport chains are exit gates where congested roads and inadequate rail links cause delays and increase transport costs. Strategic solution would be the implementation of railways and/or improved land-based intermodal terminals, i.e. dry ports serving seaports. This paper presents a decisionmaking model on the necessity to establish a dry port for serving seaport in order to increase the capacity or space of the seaport, accelerate the technological process and reduce the rush on the routes.
\end{abstract}

\section{Sažetak}

Danas se morske luke suočavaju s mnogim problemima. Jedan je od glavnih problema povećanje kontejnerskog prometa, uslijed čega se javljaju problemi poput nedostatka prostora na terminalima luke i zagušenja na rutama koje opslužuju te terminale, $t j$. povećanja uskih grla u sustavima kopnenog prometa koji opslužuju morske luke. Za neke su morske luke najslabije karike u njihovim transportnim lancima izlazi, gdje zakrčene ceste i neprikladne željezničke veze uzrokuju kašnjenja i povećavaju troškove prijevoza. Strateško rješenje bila bi uspostava željezničkog prometa i/ili poboljšanih kopnenih intermodalnih terminala, tj. suhih luka koje opslužuju morske luke. $U$ ovome radu predstavlja se model odlučivanja o potrebi uspostavljanja suhe luke za opsluživanje morske luke kako bi se povećao kapacitet ili prostor morske luke, ubrzao tehnološki proces i smanjila gužva na rutama.

\section{KEY WORDS}

decision-making model necessity for establishment

dry port

seaport

container traffic

\section{INTRODUCTION / Uvod}

Seaports often use space in urban areas and the expansion often causes environmental problems, so the use of dry ports or inland terminals in remote areas is becoming more and more an alternative to the expansion of seaports.

As container transport continues to grow, seaport access to land becomes a key factor for the competitive advantage of seaports. Thus, sole advances in the maritime section of the transport chain and in port terminals, without improving access to land via intermodal terminals, are not sufficient for the entire transport chain to function. The well-used dry port concept can shift road freight on more energy-efficient types of transport that are more environmentally friendly, such as railways that reduce city congestion, make ship handling more efficient and provide carriers with improved logistic solutions in inland areas. The dry port provides seaport with the possibility of securing the market in the hinterland, increasing the capacity without physical port expansion as well as better service for shipping and shipping operators. The main features of the dry port are: uninterrupted transport and crossing points; a regular and reliable rail link between the seaport and the dry port; dry port is equipped for handling with intermodal units; services at the dry port include: road and rail crossing, customs clearance, container maintenance, long and short storage time, road transport and logistics. $[1,6,10,11]$

Through the research conducted, it has been established that the dry port is a land terminal that is usually built for the purpose of servicing the seaport, i.e. for relieving and ensuring sufficient capacity of the seaport due to the impossibility of its further expansion, for reduction of congestion and bottlenecks on roads, for reduction of time delays in transport of goods, for reduction of environmental pollution, for outsourcing activities that do not necessarily have to be carried out at the seaport (logistic activities), etc. Given that the dry port is a major financial investment, there must be a strong justification for the need to build a dry port, i.e. if there is a seaport that does not have the possibility of physical expansion due to limited capacity, and demand for freight (in this case containers) traffic continues to grow, causing delays and congestion at the seaport, this is 
the first indicator of the need for a functional solution, i.e. the establishment of a dry port that would reduce or eliminate these problems.

The paper analyses the main indicators of the seaport operations on the example of the Rijeka Seaport to obtain information on the necessity to establish a dry port as a possible solution.

The aim of this paper is to set a new decision-making model on the necessity to establish a dry port based on the research and results obtained, and to verify the model on the example of a seaport. Rijeka Seaport in the Republic of Croatia is taken as an example of a seaport of limited capacity, which does not have the possibility of further expansion, where congestion and delays occur, and the transport demand continues to increase.

\section{REVIEW OF DECISION-MAKING AND FORECASTING METHODS / Pregled metoda odlučivanja i prognoza}

Decision-making as a term is present in every aspect of everyday life, both private and business. The goal of the decision-making process is to solve the set task at available alternatives in an optimal way, measured in accordance with its goals and values. It is necessary to explore different models for analysing the decision-making process in each phase and to present the decision-making process for the particular case according to the chosen model. It is crucial to achieve the results of research or decision-making process that will give recommendations for improvement or development.

\subsection{Review of Decision-Making Methods / Pregled metoda odlučivanja}

Given the complexity of the problem, where it is necessary to make a model for deciding on the need to establish a dry port, which implies many criteria, it is necessary to apply a multi-criteria analysis. Multi-criteria analysis is a significant tool for solving complex real problems. Multi-criteria analysis attempts to find the most effective methods for finding optimal solutions in situations where there is a greater number of conflicting criteria, triggering expert discussions about what kinds of methods are better and more reliable. There are several methods of multi-criteria analysis such as AHP method, PROMETHEE method, TOPSIS method, ELECTRE method, A'WOT method, etc. [19, 21, 23]

Among the methods of multi-criteria decision-making, AHP method (Analytical Hierarchy Process) occupies a special place. The AHP method has great importance in structuring the problem and decision-making process. By applying the AHP method, it is possible to interactively create the hierarchy of the problem that serves as the preparation for decision-making, then compare the criteria and alternate pairs, and finally synthesize all the comparisons and determine the weight coefficients of all the hierarchy elements. The sum of the weight coefficients of the elements at each hierarchy level is equal to 1 and allows the decision maker to rank all hierarchy elements by importance. [19,21,23]

The PROMETHEE method is one of the methods of multi-criteria analysis. The PROMETHEE method is the method of organizing the rank of preference for making decisions. The application of the PROMETHEE method consists of two steps: the relationship structure for each criterion in the set of alternatives and the use of these relationships to solve the multi-criteria problem. $[19,21,23]$

Because of its simplicity, business practice often uses the TOPSIS method to solve multi-criteria problems. TOPSIS is a technique for determining the order of resemblance to an ideal solution. The TOPSIS method is based on the concept that alternatives chosen should have the shortest distance from the positive ideal solution and the longest distance from the negative ideal solution. In other words, the optimal alternative is the one that is geometrically closest to the positive ideal solution, that is, the farthest from the negative ideal solution. [19,21]

$A^{\prime}$ WOT method represents technique in the decision-making process. It was combined with the Analytical Hierarchy Process and SWOT Analysis. [19,21]

ELECTRE are multi-criteria optimization procedures that allow the best choice of variants, the so-called. selecting, ranking, and sorting variants of a problem solutions, taking into account the criteria and preferences of the decision maker. The ELECTRE method presents a set of methods for solving the decision-making problem where the evaluation of alternative decisions is made by comparing the relevant criteria that characterize those decisions. This method gives option to choose the best alternatives from the given set of alternatives. For the high quality of multi-criteria optimization, it is necessary to:

Well define/ generate variants,

Appropriately choose the criteria by which the variants will be evaluated,

- Conduct an analysis of the mutual dependence of the criteria,

- Choose a multi-criteria optimization process that matches the type of problem being solved,

Implement multi-criteria optimization,

- $\quad$ Analyse the results. [19,20,21]

\subsection{Review of Forecasting Methods / Pregled metoda prognoza}

Forecasting methods assume that there is a stable regularity in the system. By combining different forecasting methods, it is more likely to obtain a better forecast than using only one method. Forecasting is used in different aspects of business: cost planning, budgeting, sales, inventory, production capacity, business activity schedules, etc. If the subject of forecasting is more susceptible to changes, the forecast will be less reliable. [22]

The choice of method to be used will be influenced by several factors: the applicability of history data, the forecasted period, the desirable degree of reliability of the forecasts, the time available for forecasting, estimated cost and benefits expected from the forecasts, availability of qualified personnel for making forecasts, etc. Forecast approaches can be qualitative and quantitative.[22]

Qualitative forecasts (subjective) are forecasts that include the intuition of decision makers, emotions, personal experiences and value system. Some of the qualitative methods are expert opinion, group consensus, historical comparisons, Delphi method, Grass Roots method, market research, etc. [22]

Quantitative forecasts are forecasts using mathematical modelling for forecasting demand. Quantitative forecasts can be time series analysis, causal models, and simulations. Combination-based forecasts are most effective in practice. In the group of time series analysis methods are moving average, weighted moving average, exponential smoothing, trend analysis and seasonal analysis. In the group of causal methods there are simple regression analysis, multi-regression analysis and general linear models. Simulations are usually performed with the help of software simulation tools. [22] 
Trend is a regularity in increasing or decreasing value. The essence of the method is that the regularities are joined with the trend line with the corresponding equation, and based on it, the projection for the future is made. The trend can be analysed using Microsoft Excel tools. There are two main types of trends: linear and exponential. The measure of the adequacy of the trend is the determination coefficient $R^{2}$, with values between 0 and 1. The closer it is to 1, the line-up of the trend line and value is better. [22]

The values which can be obtained are $a$ and $b$ as follows:

$$
\begin{aligned}
& \text { SLOPE }=a=\frac{\sum x_{i} y_{i}-n \bar{x} \bar{y}}{\sum x_{i}^{2}-n \bar{x}^{2}} \\
& \text { INTERCEPT }=b=\bar{y}-b \bar{x}
\end{aligned}
$$

where the variables are as follows:

$a$ - slope direction,

$b$ - section on $y$ axis,

$\bar{x}$ - average value of $x$ variable,

$\bar{y}$ - average value of $y$ variable,

$n$ - number of observations (measured values).

Standard error estimation is obtained as follows:

$$
s_{y x}=\sqrt{\frac{\sum\left(y_{i}-y_{i}^{\prime}\right)^{2}}{n-2}}
$$

reliability interval for the mean value is as follows:

$$
y^{\prime} \pm t s_{y x} \sqrt{\left(\frac{1}{n}+\frac{(x-\bar{x})^{2}}{S S X}\right)},
$$

reliability interval for the estimated value is as follows:

$$
y^{\prime} \pm t s_{y x} \sqrt{1+\left(\frac{1}{n}+\frac{(x-\bar{x})^{2}}{S S X}\right)}
$$

where the variables are as follows:

$y^{\prime}$ - forecasted value,

$t$ - value for $\mathrm{t}$-distribution with $\mathrm{n}-2$ degrees of deviation,

$s_{y x}$ - standard error estimation,

$n$ - number of observations,

SSX - sum of squared deviations of independent variable (x),

\section{RIJEKA SEAPORT CONTAINER TERMINAL} CAPACITY AND CONTAINER TRAFFIC / Kapacitet kontejnerskog terminala morske luke rijeka $i$ kontejnerski promet

3.1. Rijeka Seaport Container Terminal Capacity / Kapacitet kontejnerskog terminala morske luke Rijeka The container traffic of Rijeka Seaport is carried out almost entirely on the Rijeka Seaport container terminal Adriatic Gate Container Terminal (AGCT), also called "Brajdica" (Figure 1), which is located on the eastern side of the Rijeka Basin, in the very centre of Rijeka. During the 25 years since the first phase, i.e. when the first part of the terminal has been released to service, the amount of throughput load is continuously increasing. In 2001, the company "Jadranska vrata" was founded as a daughter company of Rijeka Seaport, which has been in charge of seaport container traffic. $[12,13,14,15,16,17,18,24,25]$

In 2011 in the ownership structure of "Jadranska vrata" has changed. International Container Terminal Services Inc. (abbreviated ICTSI) becomes strategic partner with a 51\% share with a concession for 30 years, i.e. up to 2041, while Rijeka Seaport keeps the remaining $49 \%$ of the share. After joining the strategic partner, the terminal "Jadranska vrata" was renamed to Adriatic Gate Container Terminal (AGCT) to make it more recognizable in the world. The largest investment by ICTSI, which is specialized in the operation of container terminals worldwide, is focused on the implementation of modern technologies, i.e. IT systems that allow automatic monitoring of loading/ unloading, warehousing, and shipping containers. In addition to the implementation of modern technologies, ICTSI will work to increase the efficiency of the Adriatic Gate Container Terminal, as well as to expand its gravitational impact on Hungary, the Czech Republic, Slovakia, Poland, and predominantly Serbia and Bosnia and Herzegovina. The terminal capacity of AGCT is 450,000 TEU per year while the expansion is planned up to 600,000 TEU per year. $[12,13,14,15,16,17,18,24,25]$

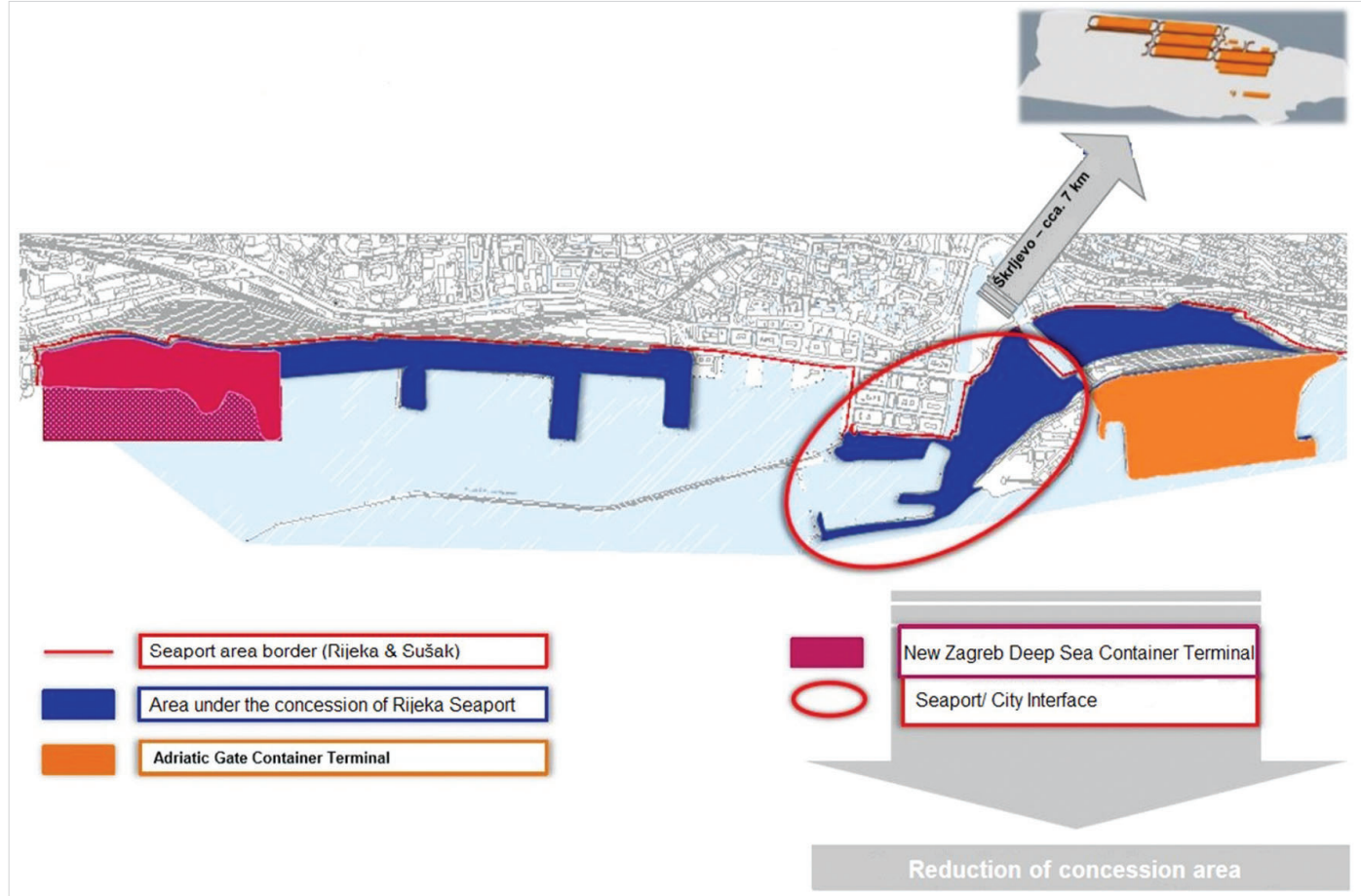

Figure 1 Rijeka Seaport Area/Terminals

Slika 1. Zona/terminali morske luke Rijeka

Source: Created by authors according Rijeka Seaport Management Presentation form 2015, https://lukarijeka.hr/ 
In addition to the AGCT, due to the need for further increase in loading/ unloading and storage capacity, Rijeka Seaport is building a new container terminal in the western part of the Rijeka Basin. The new container terminal is named Zagreb Deep Sea Container Terminal and will eventually occupy an area of approximately 22 hectares. The terminal is designed with $680 \mathrm{~m}$ length and $300 \mathrm{~m}$ width, and the planned capacity of the new Zagreb Deep Sea Container Terminal is approximately 500,000 TEU per year. $[13,14,15,16,17,18,24,25]$

\subsection{Rijeka Seaport Container Traffic / Kontejnerski promet morske luke Rijeka}

Container traffic at Rijeka Seaport from 1993 to 2019 has been continuously increasing in general, although there were certain periods or years when various factors such as the global crisis, decreased purchasing power of end users, or the exceptional growth of the competitors caused a decrease in container traffic to the Rijeka Seaport. If we observe the period from 1993 to 2019 in which the Rijeka Seaport recorded a very significant increase in container traffic, which is today the most important form of maritime freight transport, the Rijeka Seaport has become one of the most important seaports in the northern Adriatic Sea. The successful operation of Rijeka Seaport positively reflects not only the development of the seaport itself, but also the economic development of the entire Republic of Croatia. Therefore, it is essential that capital investments continue in the container terminal, even in the years when Rijeka Seaport container traffic is decreased, because such investments give a positive result in a very short time, thus increasing the competitiveness of Rijeka Seaport on the global market. Graph 1 illustrates the overview of container traffic at Rijeka Seaport in the period from 1993 to 2019 (in TEU). [14,17,24,25]

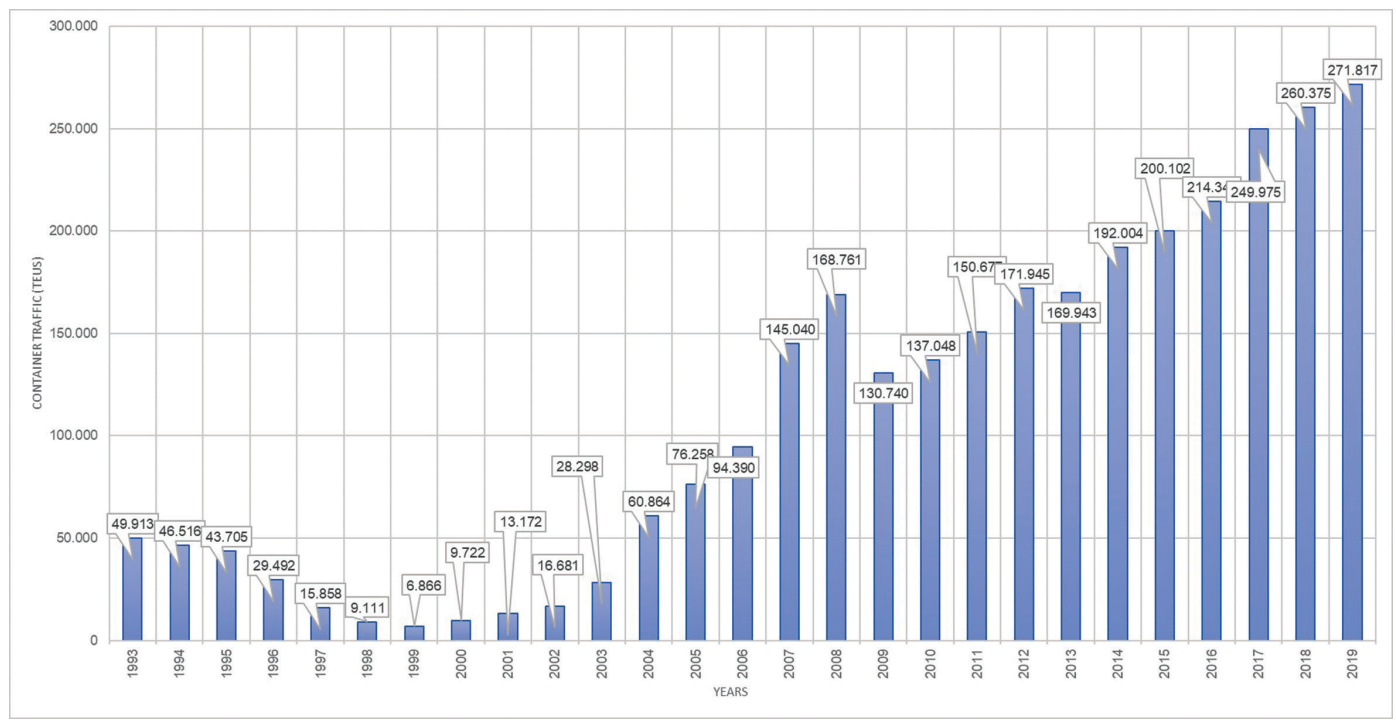

Graph 1 Overview of Container Traffic at Rijeka Seaport in the Period from 1993 to 2019 (in TEU)

Grafikon 1. Pregled kontejnerskog prometa u morskoj luci Rijeka u razdoblju 1993. - 2019. (U TEU)

Source: Created by authors based on statistical data of Rijeka Seaport

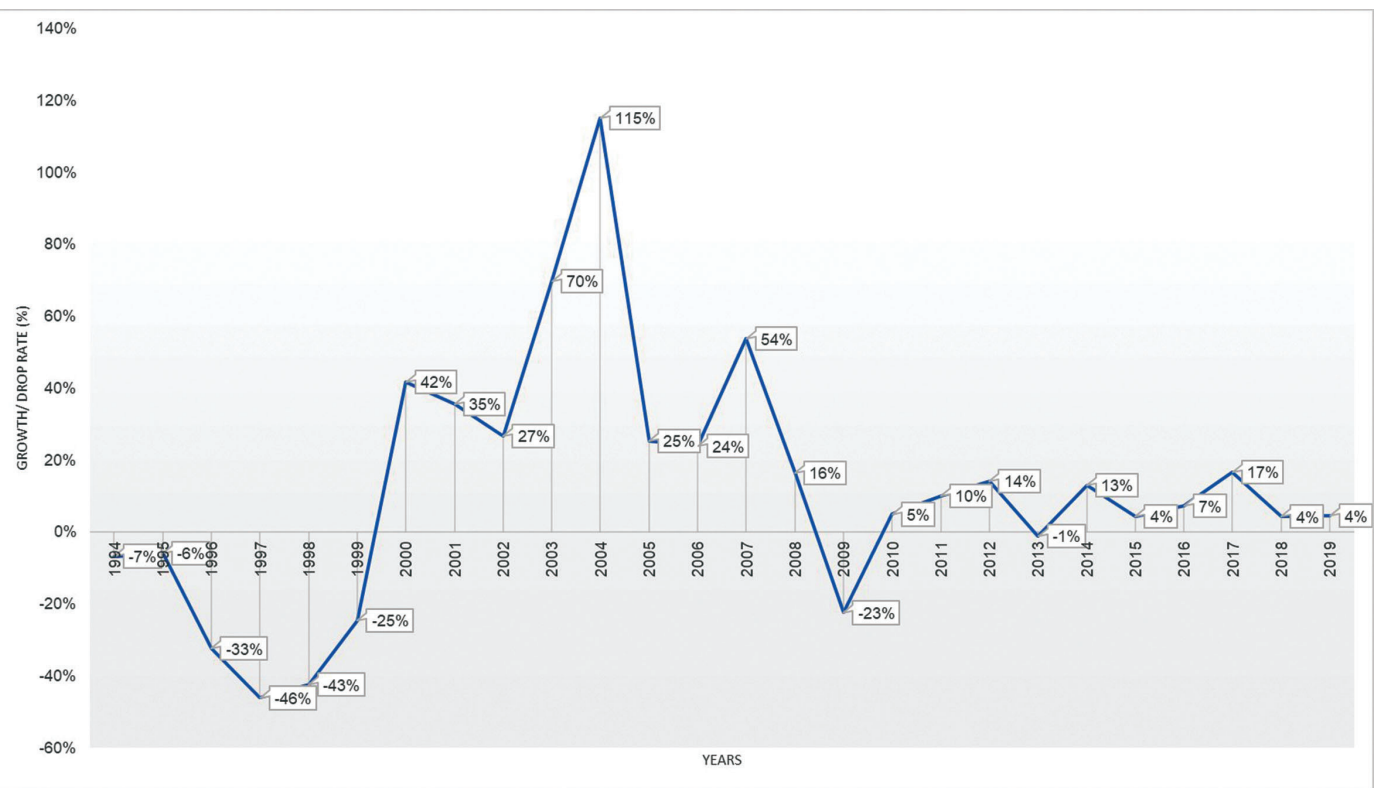

Graph 2 Overview of Total Container Traffic Growth in the Period from 1993 to 2019 in Percentage (\%)

Grafikon 2. Pregled ukupnog rasta kontejnerskog prometa u razdoblju 1993. - 2019. u postocima

Source: Created by authors based on statistical data of Rijeka Seaport 


\subsection{Forecast of Container Traffic at Rijeka Seaport / Prognoza kontejnerskog prometa u morskoj luci Rijeka} Forecast of container traffic at Rijeka Seaport is done by trend analžysis with use of Microsoft Excel forecasting tools for the period 2020-2041. Table 1 shows forecasted values of container traffic at Rijeka Seaport in the period 2020-2041, and Graph 3 illustrates forecasted values of container traffic at Rijeka Seaport in the period 2020-2041. [24,25]

\subsection{Comparison of Rijeka Seaport Capacity and Container Traffic / Usporedba kapaciteta i kontejnerskog prometa morske luke Rijeka}

The comparison analysis of Rijeka Seaport capacity and container traffic forecast for the period from 2020 to 2041 indicates that existing capacity of Adriatic Gate Container Terminal (AGCT) will be reached in year 2036 but according to upper limit of forecast, in year 2027. The planned expansion of

Table 1 Forecast of Container Traffic at Rijeka Seaport in the Period 2020-2041 Tablica 1. Prognoza kontejnerskog prometa u morskoj luci Rijeka u razdoblju 2020. - 2041.

\begin{tabular}{|c|c|c|c|c|}
\hline Timeline & Total (in TEU) & Forecast & Lower Limit of Reliability & Upper Limit of Reliability \\
\hline 1993 & 49.913 & & & \\
\hline 1994 & 46.516 & & & \\
\hline 1995 & 43.705 & & & \\
\hline 1996 & 29.492 & & & \\
\hline 1997 & 15.858 & & & \\
\hline 1998 & 9.111 & & & \\
\hline 1999 & 6.866 & & & \\
\hline 2000 & 9.722 & & & \\
\hline 2001 & 13.172 & & & \\
\hline 2002 & 16.681 & & & \\
\hline 2003 & 28.298 & & & \\
\hline 2004 & 60.864 & & & \\
\hline 2005 & 76.258 & & & \\
\hline 2006 & 94.390 & & & \\
\hline 2007 & 145.040 & & & \\
\hline 2008 & 168.761 & & & \\
\hline 2009 & 130.740 & & & \\
\hline 2010 & 137.048 & & & \\
\hline 2011 & 150.677 & & & \\
\hline 2012 & 171.945 & & & \\
\hline 2013 & 169.943 & & & \\
\hline 2014 & 192.004 & & & \\
\hline 2015 & 200.102 & & & \\
\hline 2016 & 214.348 & & & \\
\hline 2017 & 249.975 & & & \\
\hline 2018 & 260.375 & & & \\
\hline 2019 & 271.817 & 271.817 & 271.817 & 271.817 \\
\hline 2020 & & 281.720 & 246.966 & 316.474 \\
\hline 2021 & & 291.790 & 245.010 & 338.570 \\
\hline 2022 & & 301.860 & 245.548 & 358.172 \\
\hline 2023 & & 311.930 & 247.464 & 376.396 \\
\hline 2024 & & 322.000 & 250.285 & 393.714 \\
\hline 2025 & & 332.070 & 253.761 & 410.378 \\
\hline 2026 & & 342.139 & 257.738 & 426.541 \\
\hline 2027 & & 352.209 & 262.114 & 442.305 \\
\hline 2028 & & 362.279 & 266.817 & 457.741 \\
\hline 2029 & & 372.349 & 271.795 & 472.903 \\
\hline 2030 & & 382.419 & 277.009 & 487.829 \\
\hline 2031 & & 392.489 & 282.427 & 502.551 \\
\hline 2032 & & 402.559 & 288.024 & 517.094 \\
\hline 2033 & & 412.629 & 293.780 & 531.477 \\
\hline 2034 & & 422.698 & 299.678 & 545.719 \\
\hline 2035 & & 432.768 & 305.704 & 559.832 \\
\hline 2036 & & 442.838 & 311.847 & 573.829 \\
\hline 2037 & & 452.908 & 318.096 & 587.720 \\
\hline 2038 & & 462.978 & 324.442 & 601.514 \\
\hline 2039 & & 473.048 & 330.878 & 615.218 \\
\hline 2040 & & 483.118 & 337.397 & 628.839 \\
\hline 2041 & & 493.188 & 343.993 & 642.383 \\
\hline
\end{tabular}

Source: Created by authors based on statistical data of Rijeka Seaport using Microsoft Excel prediction tools (trend analysis) 


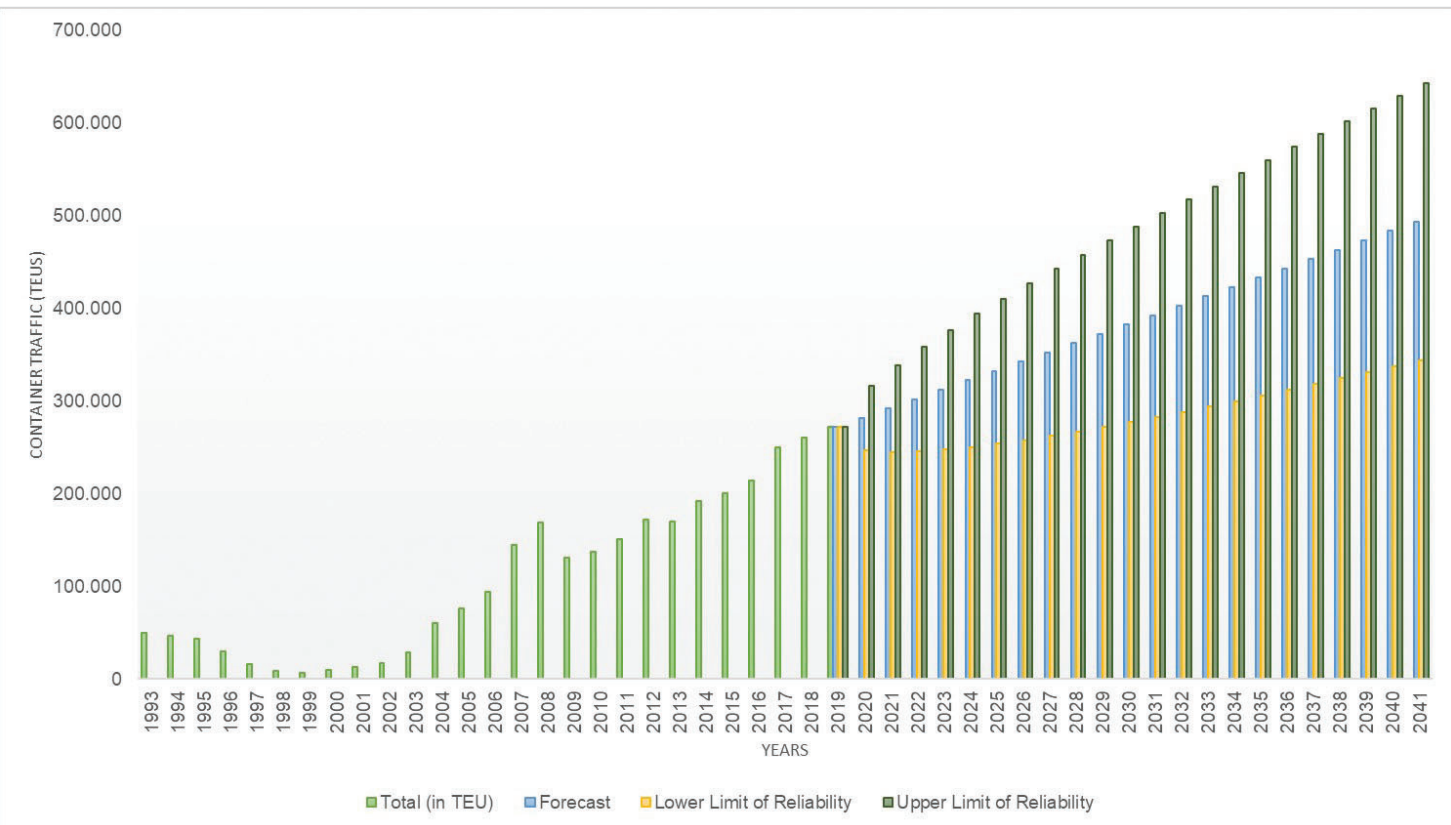

Graph 3 Forecast of Container Traffic at Rijeka Seaport in the Period 2020-2041

Grafikon 3. Prognoza kontejnerskog prometa u morskoj luci Rijeka u razdoblju 2020. - 2041.

Source: Created by authors based on statistical data of Rijeka Seaport using Microsoft Excel prediction tools (trend analysis)

AGCT is expected to be up to 600,000 TEU units per year, and it is evident that capacity of 600,000 TEU units per year will be reached according to upper limit of forecast, in year 2038 (Graph 4). Building a new Zagreb Deep Sea Container Terminal, which is planned to have capacity of 500,000 TEU units per year, provides assurance for continuously increasing container traffic at Rijeka Seaport (Graph 5). [24,25]

\subsection{Simulation of the Rijeka Seaport Operations / Simulacija poslova u morskoj luci Rijeka}

For the Rijeka Seaport to increase its capacity, which will be necessary due to the increase of container traffic in past 20 years, and without large investments, one of the possible solutions is the construction of a dry port terminal. A well-designed dry port concept can shift cargo from the road to more energy efficient modes of transport that are less harmful to the environment, reduce congestion in cities, make handling of goods in seaports more efficient and make it easier for carriers to improve logistics solutions in seaport hinterland. A dry port can speed up the flow of cargo between ships and major transport networks, creating a central distribution point. Dry ports can improve the movement of cargo, in this case containers, by moving sorting and processing of containers to dry port facilities, far away from congested seaports. Zagreb, Miklavlje and Vinkovci were chosen

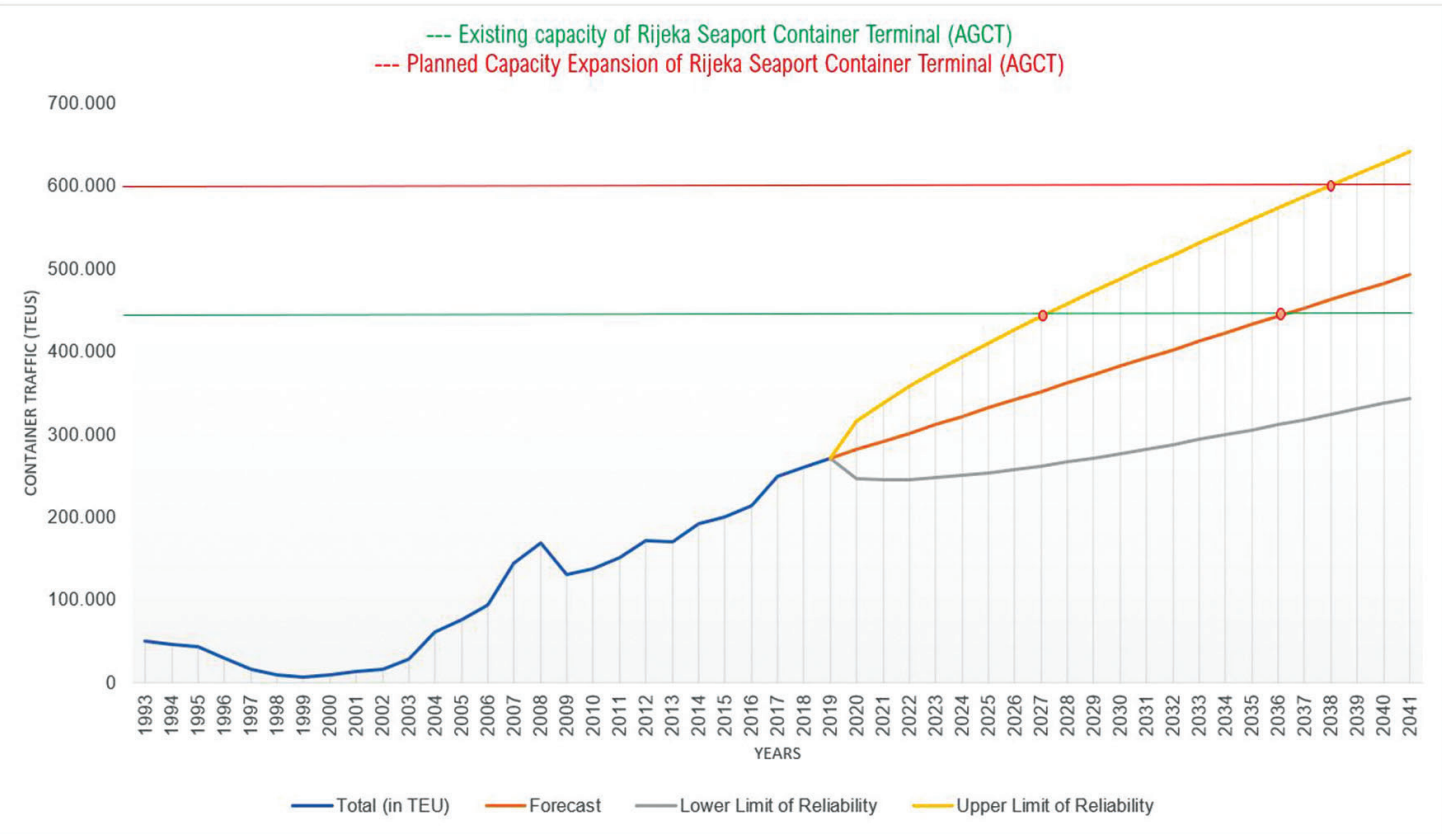

Graph 4 Comparison of Existing/ Planned Capacity vs. Container Traffic Forecast - 2027, 2036, 2038

Grafikon 4. Usporedba postojećih/planiranih kapaciteta nasuprot prognozi kontejnerskog prometa - 2027., 2036., 2038.

Source: Created by authors based on statistical data of Rijeka Seaport using Microsoft Excel prediction tools (trend analysis) 


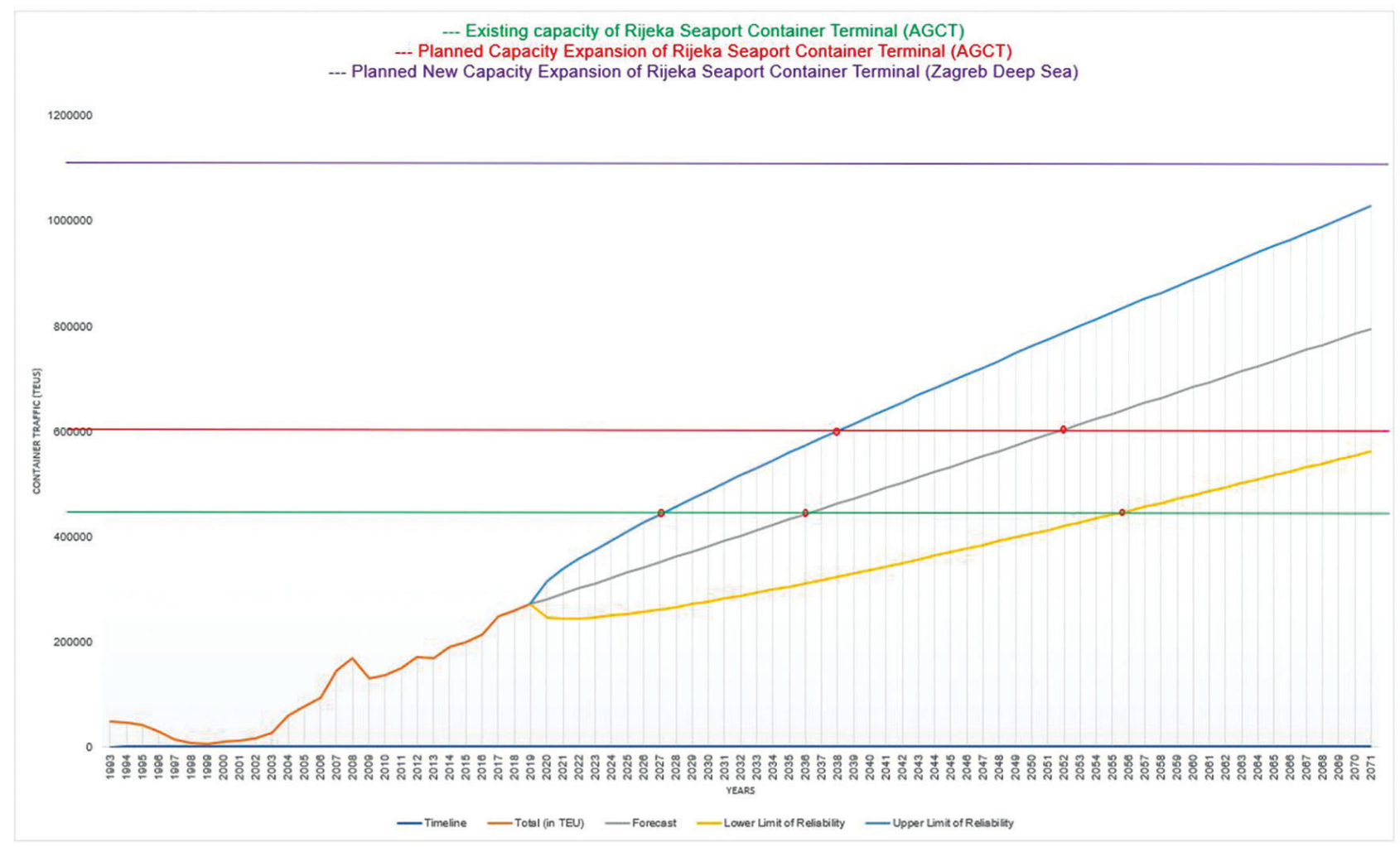

Graph 5 Overview of Existing/ Planned/ New Capacity vs. Container Traffic Forecast by 2041

Grafikon 5. Pregled postojećih/novih/planiranih kapaciteta nasuprot prognozi kontejnerskog prometa do 2041.

Source: Created by authors based on statistical data of Rijeka Seaport using Microsoft Excel prediction tools (trend analysis)

as possible locations for a dry port, primarily because of their geographical positions and existing infrastructure features. Four simulations were made for existing set-up without a dry port and for all three possible solutions to find the optimal solution and to see if it would speed up the transport process of cargo, specifically containers, and consequently increase the capacity of the Rijeka Seaport and eliminate bottlenecks and congestion at the Seaport Rijeka. [26] Details of the simulations are outlined in source [26].

Simulation of the operation of the seaport or technological processes of the container terminal of the seaport using software tools to gain insight into the transport time intervals of

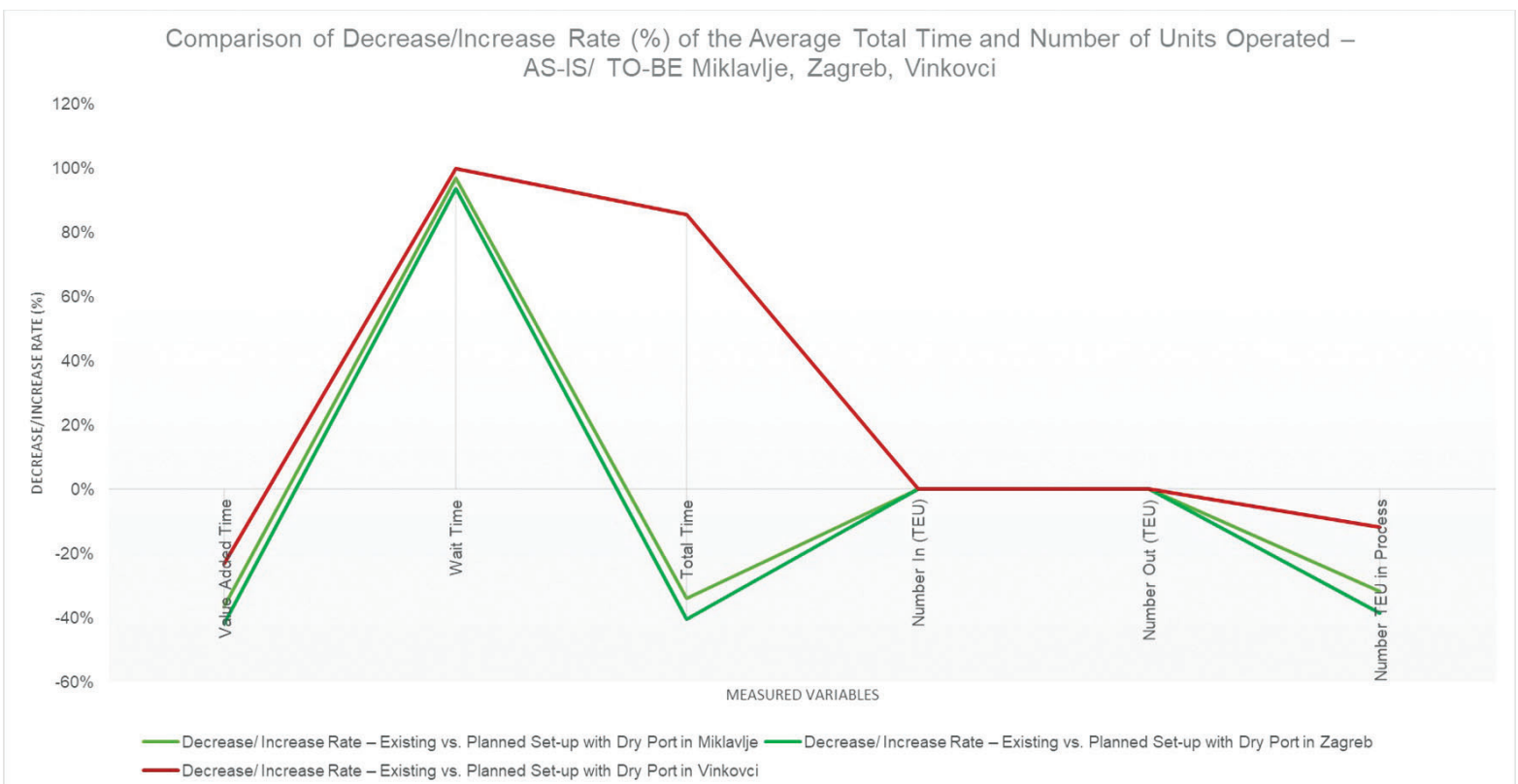

Graph 6 Comparison of Decrease/Increase Rate (\%) of the Average Total Time and Number of Units Operated - AS-IS/TO-BE Miklavlje, Zagreb, Vinkovci

Grafikon 6. Usporedba stope smanjenja/povećanja (\%) prosječnog ukupnog vremena i broja jedinica koje rade - AS-IS/TO-BE Miklavlje,

Source: [26]

$$
\text { Zagreb, Vinkovci }
$$




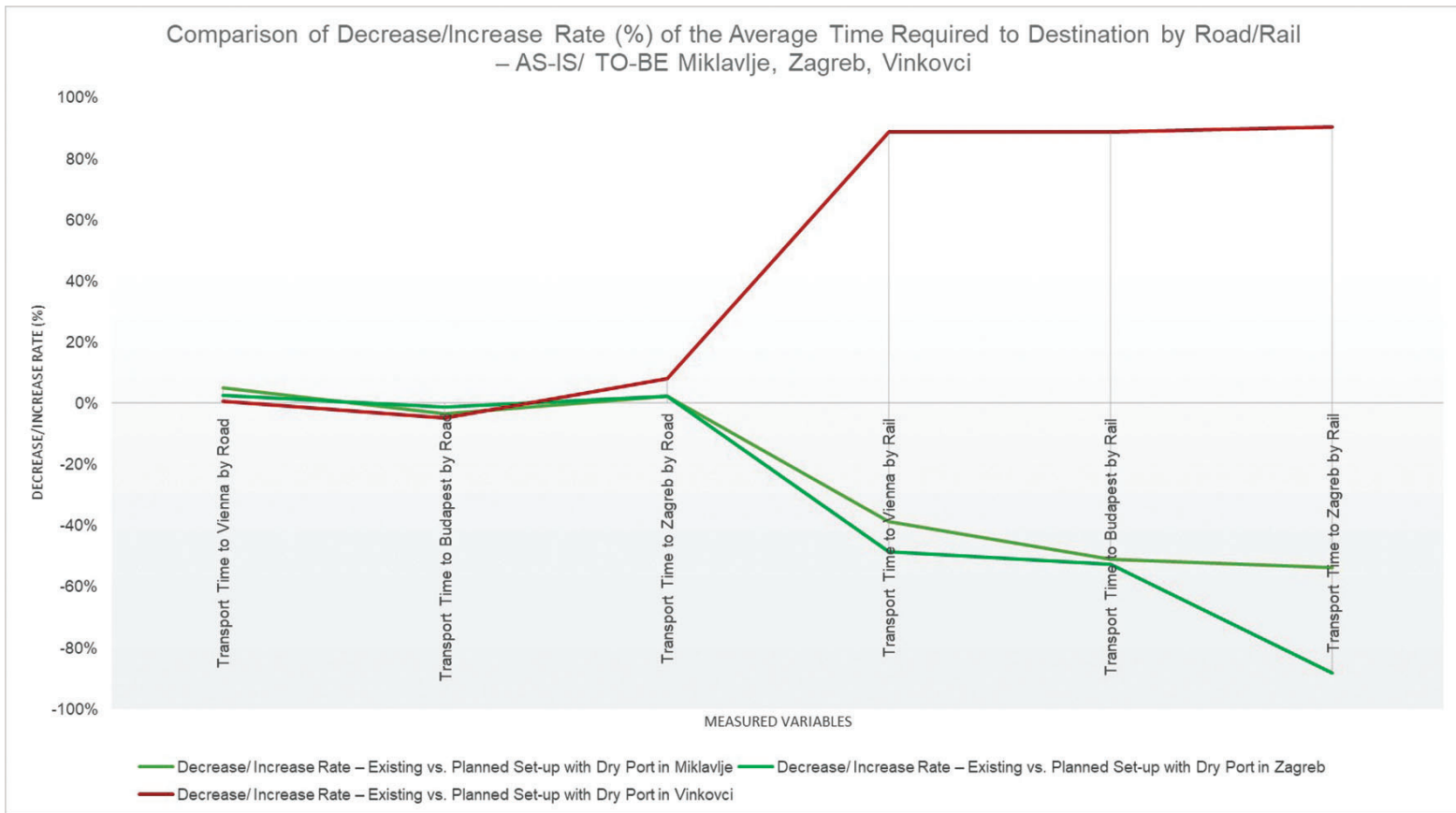

Graph 7 Comparison of Decrease/Increase Rate (\%) of the Average Time Required to Destination by Road/Rail - AS-IS/TO-BE Miklavlje, Zagreb, Vinkovci

Grafikon 7. Usporedba stope smanjenja/povećanja (\%) prosječnog vremena potrebnog do destinacije cestom/željeznicom AS-IS/TO-BE

Source: [26] Miklavlje, Zagreb, Vinkovci

a particular part of the transport process at the seaport. For the example of the Rijeka Seaport in the existing set-up and future possible set-up with established dry port, the simulations were created using the software tool Arena Simulation Software. [26] The results provide a good basis and a better picture of the process for future comparison with the simulation of a seaport process with an established dry port. For Rijeka Seaport (Graph 6 and Graph 7), the results show that the process is faster and more ecologically acceptable with the use of dry port. The simulations showed significant savings in transport time using rail.

\section{ADVANTAGES OF SEAPORT WITH ESTABLISHED DRY PORT / Prednosti morske luke koja ima uspostavljenu suhu luku}

As container transport continues to grow, seaport access to land becomes a key factor for the competitive advantage of seaports. Consequently, sole advancement on the sea part of the transport chain and on the terminals of the seaports, without improving access to the seaports via the intermodal terminals, is not sufficient for the entire transport chain to function. [5] As a consequence, the emphasis of this paper is also the importance of effective access to inland ports that will be enabled through the implementation of dry ports.

Previous research results show that the dry port concept, in addition to the general benefits of environmental protection and quality of life, by shifting the flows from the road to the railroad, offers seaports a possibility of increasing the capacity without physical expansion in the area of the seaport. [2]

With the increase in the amount of freight in maritime container transport, the seaport and their land access became limited to the critical point. One potential solution is the dry port concept for the seaport. Land usage, infrastructure, environmental protection, and institutional barriers have been identified as most often barriers in this case. The dry port must fit into a complex system where the on-site infrastructure is in place, as well as the maintenance, and the legislative, regulatory, and institutional system is properly set up to optimize the involvement of the public and private sector. $[3,4]$

Transport systems were always designed according to geographic conditions as well as transport requirements, which were determined by the amount of transported goods and the quality of the service. Currently, environmental protection issues also play a major role in design. One way to achieve these demands is to use railways through intermodality. In order to stimulate the development of intermodal transport chains, the concept of dry port must be set. [3]

Faster moving of containers from seaport to end destination also increases seaport capacity. Implementation of the dry port in the seaport transport system, or the seaport hinterland, creates a steady transport chain, a smooth flow of the single interface in the form of a dry port concept. However, significant time savings, as well as financial savings, can only be achieved by avoiding waiting lines at the seaports and moving storage containers on land. Expanding to new markets improves seaport access to an area beyond its traditional hinterland, resulting in new users and greater profits and promoting regional economic activities. $[1,3,4,7]$

According to the results conducted in the paper, the construction of a dry port that would serve Rijeka Seaport, would be profitable in terms of full connection and inclusion of the Republic of Croatia in the EU transport network TEN-T, introduction of railways instead of roads, which would ensure reduction of air, water and soil pollution, speed up the process of container transport and compliance with regulatory requirements, and most importantly would increase the capacity of the seaport, relieve seaport of congestion and ensure the flow of goods more evenly and efficiently. 


\section{CONCEPT OF THE DECISION-MAKING MODEL ON NECESSITY OF ESTABLISHING SEAPORT DRY PORT / Koncept modela odlučivanja o potrebi uspostavljanja suhe luke za morsku luku}

From the basic settings and desired outcomes, the criteria emerge on the basis of which it is necessary to create and evaluate existing and new solutions, in order to match their choice with the set goals or outcomes.

Decision-making criteria are the most important part of the decision-making process because they are used to design and evaluate models. The criteria are designed to formulate the problems that arise while designing and selecting the most appropriate solution, and to make good and quality decisions based on them. Choice of criteria is also important, i.e. it is necessary to evaluate those criteria which directly influence the decision-making process. [2,8,9]

A conceptual decision-making model on the necessity to establish a dry port has been set based on the overall research conducted in the previous chapters. The model consists of 14 steps, where each step implies a cause-and-effect relationship, and it can be applied in any decision-making process regarding necessity to establish a dry port in the service of a seaport.

Using the decision-making methods outlined in 2.1, specifically AHP method, the following key factors are chosen: dry port terminal infrastructure (capacity and existing conditions), dry port transport infrastructure (road, rail, intermodal, etc .; capacity and conditions), intensity of transport flows and acceleration of transport of goods by establishing a dry port, providing additional capacity and relieving the activities at the seaport by establishing a dry port, presence and cooperation of dry port service providers (operators, representative offices, associations, etc.), public-private or state ownership (dry port organizational structure), reducing emissions/ reduction of air pollution and soil, the impact of the environment on the goods in the terminal and the impact of the goods and processes in the terminal on the environment, advanced IT systems, container tracking systems, investment of the construction of access roads and terminal infrastructure and the period of return of means, facilitating international trade and encouraging economic development, fitting into spatial urban plans and complying with all applicable regulations, integration into the railway transport development policy in the EU, positioning in the TEN-T network, impact on the regional development (cohesion factor).

The most important criteria that point to the sole necessity of establishing a dry port (considering all the key factors) are as follows:

- Seaport capacity vs. container traffic/ future demand (general and statistical data),

- Technological process in the existing set-up vs. technological process in the simulated set-up with dry port (transport time/ delays/ processing speed),

- Connection with key traffic corridors, i.e. the location of the dry port (TEN-T network),

Impact on the development of the region (cohesion factor), Possibility of further development of intermodal container traffic.

The decision-making model on the necessity to establish a dry port consists of several key steps:

1. Collecting data (case-study, collecting all relevant data on a targeted seaport for determining the necessity to establish a dry port),

2. Capacity analysis (key criterion and input parameter to determine the necessity to establish a dry port, dry port provides additional capacity),

3. Traffic analysis (analysis of seaport container traffic, collection of historical statistical traffic data),

4. Capacity development (gathering data on planned infrastructural work, existing and planned projects),

5. Traffic forecast (forecast of future container traffic of the seaport according to statistical seaport data for the next 1020 years, use of forecasting methods such as trend analysis, moving averages, software tools),

6. Comparison of capacity vs. traffic (comparison of collected data on the existing and planned capacity of the seaport in relation to the trend (increase or decrease) of the forecast traffic),

7. Simulation of the seaport operations (simulation of the technological processes of the seaport container terminal with the use of software tools),

8. Collecting data on dry ports,

9. Establishing key criteria for establishing a dry port,

10. Choice of dry port location (choice of location using decisionmaking methods such as the ELECTRE method which, based on various variants, shows the optimal solution i.e. location),

11. Simulation of seaport operations with dry port (simulation of the technological processes of the seaport with established dry port using software tools),

12. Comparison of a seaport with and without established dry port (comparison of the technological process of one and the other version for the purpose of determining the advantages/ benefits of seaport with established dry port),

13. Comparison/validation of all results,

14. DECISION.

\section{DECISION-MAKING MODEL ON NESSESITY OF ESTABLISHING DRY PORT ON THE SAMPLE OF RIJEKA SEAPORT / Model odlučivanja o potrebi uspostavljanja suhe luke na primjeru morske luke Rijeka}

Implementing the decision-making model described in Chapter 5 on the sample of Rijeka Seaport, the results are described in the following text, according to 14 steps of the decision-making model.

The first step is to collect all relevant data on the target seaport for which the necessity to establish a dry port needs to be determined. On the example of the Rijeka Seaport, it was found that it suffers from congestion, that there is no significant possibility of physical expansion, that freight traffic, specifically container traffic increases from year to year, etc. From the collected basic and statistical data of the Rijeka Seaport, it can be concluded that Rijeka Seaport has a need for expansion (potentially the establishment of a dry port primarily due to the impossibility of physical expansion because it is located in the urban area of the city of Rijeka).

The second step is the analysis of the collected capacity data which is one of the key criteria and input parameter for determining the necessity to establish a dry port. The establishment of a dry port provides additional space or capacity of the seaport. On the example of the Rijeka Seaport, 


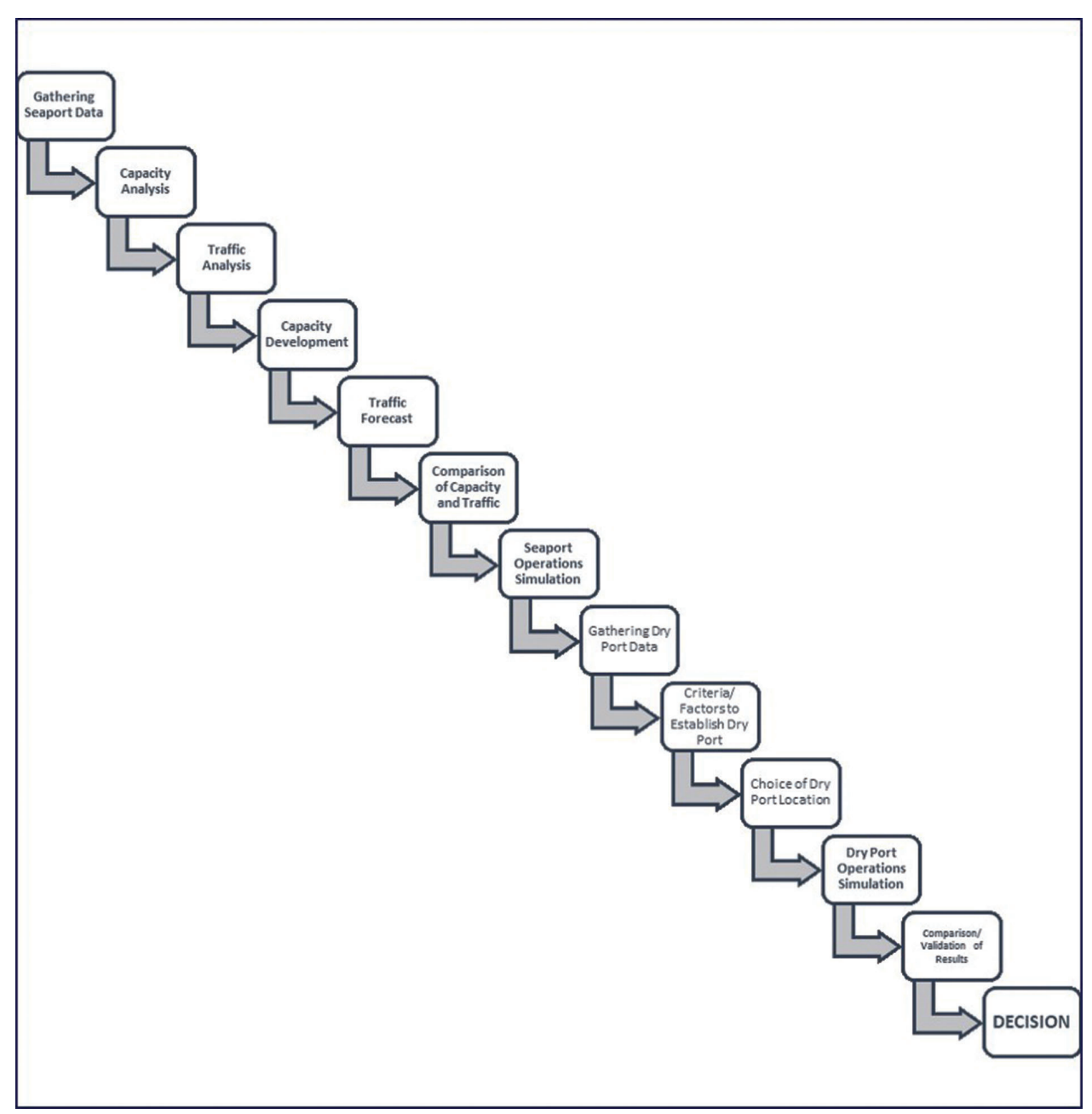

Figure 2 The Decision-Making Model on the Necessity to Establish Dry Port Slika 2. Model odlučivanja o potrebi uspostavljanja suhe luke

Source: Created by authors

it was determined that the capacity is 450,000 TEU per year. Considering that the container traffic increased from 130,740 TEU units in 2009 to 271,817 TEU units in 2019, which is an increase of $57 \%$ in a ten-year period, there is a clear risk of exceeding the capacity of the Rijeka Seaport in the next 5-10 years.

The third step is to collect all available historical statistics on container traffic and to analyse the collected data. For the example of the Rijeka Seaport, statistical data on container traffic for the period from 1993 to 2019 were collected, which show an almost continuous growth of container traffic from year to year.

The fourth step is to collect data on the development of the seaport's capacity, i.e. on the planned works, construction of additional infrastructure, existing and planned projects. On the example of the Rijeka Seaport of, it was determined that the planned expansion of the AGCT container terminal up to 600,000 TEU per year and the construction of a new terminal Zagreb Deep Sea that would provide additional capacity of 500,000 TEU per year.

The fifth step is the forecast of future container traffic of the seaport according to the statistical data of the port for the next period of 10-20 years, using forecasting methods such as time series, software tools, etc. On the example of statistical data on container traffic of the Rijeka Seaport, a forecast of container traffic from 2020 to 2041 was made. The forecast indicates a significant increase in container traffic in the observed period.

The sixth step is to compare the collected data on the existing and planned capacity of the seaport in relation to the trend (increase or decrease) of the forecasted seaport traffic. On the example of the Rijeka Seaport, a comparison of capacity and forecasted traffic was made. The intersections of the curves indicate overruns in 2027, 2036, and 2038.

The seventh step is to make a simulation of the operation of the seaport or technological processes of the container terminal of the seaport using software tools to gain insight into the time intervals of a particular part of the transport process at the seaport. For the example of the Rijeka Seaport in the existing set-up and future possible set-up with established dry port, the simulations ware created using the software tool Arena Simulation Software. The results provide a good basis and a better picture of the process for future comparison with the simulation of a seaport process with an established dry port. For Rijeka Seaport, the results show that the process is faster and more ecologically acceptable with the use of dry port.

The eighth step involves collecting data on dry ports. After the first seven steps, it can be determined with certainty whether there is a necessity to establish a dry port. On the example of the Rijeka Seaport, it can be concluded on the basis of previously implemented steps that the Rijeka Seaport needs expansion and additional capacity, which can be solved by establishing a dry port. However, in further steps, it is necessary to collect 
and analyse all data on dry ports and the factors influencing the establishment of dry ports, so that a final decision on the establishment can be made.

In the ninth step, the factors influencing the establishment of a dry port are determined as well as the key factors. For the example of the seaport of Rijeka, 54 factors of influence in the establishment of a dry port have been defined and described. Of these, 16 key factors for dry port establishment were determined, which were analysed and ranked using multicriteria analysis methods, in order to obtain priority factors for dry port establishment.

The tenth step is the selection of the location of the dry port of the seaport using key factors and decision-making methods such as the ELECTRE method, which determines the optimal solution or location based on various variants. For the example of the Rijeka Seaport, the selected locations of dry ports were Miklavlje, Zagreb and Vinkovci, in order to fit in with most of the required location criteria and the specific geo-traffic position on the trans-European corridors. In order to determine the optimal location, it is necessary to make simulations of the operation of a seaport with a dry port.

Step 11 involves simulating the operation of a seaport with a dry port at selected locations (simulation of technological processes of a container port of a seaport with an established dry port using software tool Arena), in order to confirm travel time savings and more efficient and environmentally friendly rail transport. For the example of the Rijeka Seaport, the selected locations of dry ports were Miklavlje, Zagreb and Vinkovci, and 3 simulations were made for each location. The simulations showed significant savings in travel time using rail.

Step 12 involves comparing the operation of the seaport with and without the established dry port (comparison of the technological process of both versions in order to determine the advantages of the seaport version with the dry port - relief of the seaport, higher daily capacity of receiving/ dispatching containers, etc.). For the example of the Rijeka Seaport, the selected locations of dry ports were Miklavlje, Zagreb and Vinkovci, for which simulations were made and 3 comparisons and analysis of simulation results were made, which showed the obvious advantage of seaports with established dry ports in relation to Rijeka Seaport without dry ports.

Step 13 is the comparison, validation and verification of all research results and analyses for the purpose of making a final decision. All the obtained research results can be summarized on the example of the Rijeka Seaport. So, as previously mentioned, the Rijeka seaport, there is no possibility of further physical expansion, there are large congestions on roads, the terminal is becoming more and more congested, freight traffic, especially container traffic increases every year, since the beginning of work with containers, container traffic has increased by approximately $83 \%$ from 1993 until today, which shows continuous growth, and the forecasts for the next 20 years confirm the continuation of the growth of container traffic even faster than the previous period. The capacities of the Rijeka Seaport in 5-10 years could be reached and exceeded, which necessarily requires solutions in terms of additional capacity for the Rijeka Seaport. One of the solutions is the introduction of a dry port that will serve the Rijeka Seaport. Based on the observed aspects of the impact factors and their analyses, three possible locations for the establishment of a dry port in the hinterland of the Rijeka Seaport that meet most of the selection criteria were selected: in Miklavlje, Zagreb, Vinkovci. In order to select the optimal location, simulations of the technological process of container transport from the Rijeka Seaport to the destinations of Vienna, Budapest, Thessaloniki were made. The results of the simulations showed that all locations for the establishment of a dry port reduce the time of container transport using the railway, and the optimal location was confirmed in Zagreb.

Step 14 is deciding on the need to establish a dry port. On the example of the Rijeka Seaport, it can be concluded from all research results that there is a very justified and proven need for the Rijeka Seaport to establish a dry port, and given the lack of alternative solutions, it may be the only solution. Research has shown that the optimal location is to establish a dry port in Zagreb.

\section{CONCLUSION / Zaključak}

In the interest of Rijeka Seaport competitiveness in the Northern Adriatic Sea in the future, Rijeka Seaport must continuously develop and expand in order to meet the future demands, especially in the area of container traffic which has continually grown in last 20 years. Besides projects of Rijeka Seaport container terminal(s) development, the dry port represents very convenient solution for the future increase of container traffic. Previous research results show that the dry port concept, in addition to the general benefits of environmental protection and quality of life, by shifting the flows from the road to the railroad, offers seaports a possibility of increasing the capacity without physical expansion in the seaport area.

Decision-making and forecasting methods are described in the paper. AHP method was used to determine factors influencing establishment of a new dry port, and the essential criteria were obtained to determine the need for establishing new dry port. The most important criteria that point to the necessity of establishing a dry port are: seaport capacity, container traffic/ future demand, technological process (time/ delays/ processing speed), connection with key traffic corridors, i.e. the location of the dry port (TEN-T network), impact on the development of the region, and possibility of further development of intermodal container traffic.

The analysis and simulations were conducted in the paper to confirm most important criteria in the process of determining the necessity for dry port establishment. Based on statistical data of Rijeka Seaport in the period from 1993 to 2019, this paper shows overall growth of container traffic, and presents the forecast of further growth in the future years. Forecast of container traffic at Rijeka Seaport is done by trend analysis with use of Microsoft Excel forecasting tools for the period 2020-2041. The comparison analysis of Rijeka Seaport capacity and container traffic forecast for the period from 2020 to 2041 indicates that existing capacity of Rijeka Seaport Container Terminal (AGCT) will be reached in year 2036 but according to upper limit of forecast, in year 2027. The planned expansion of AGCT is expected to be up to 600,000 TEU units per year, and it is evident that capacity of 600,000 TEU units per year will be reached according to upper limit of forecast, in year 2038. Building a new Zagreb Deep Sea Container Terminal, which is planned to have capacity of 500,000 TEU units per year, provides assurance for continuously increasing container traffic at Rijeka Seaport. 
Simulation of the operation of the seaport or technological processes of the container terminal of the seaport using software tools to gain insight into the transport time intervals of a particular part of the transport process at the seaport. For the example of the Rijeka Seaport in the existing set-up and future possible set-up with established dry port, the simulations were created using the software tool Arena Simulation Software. Zagreb, Miklavlje and Vinkovci were chosen as possible locations for a dry port, primarily because of their geographical positions and existing infrastructure features. Four simulations were made for existing set-up without a dry port and for all three possible solutions to find the optimal solution and to see if it would speed up the transport process of cargo, specifically containers, and consequently increase the capacity of the Rijeka Seaport and eliminate bottlenecks and congestion at the Seaport Rijeka. The results show that the process is faster and more ecologically acceptable with the use of dry port. The simulations showed significant savings in transport time using rail.

Due to the outlined research and conducted analysis, the paper presents a concept of decision-making model on the necessity to establish a dry port with the example of Rijeka Seaport. The construction of a dry port that would serve Rijeka Seaport, would be profitable in terms of full connection and inclusion of the Republic of Croatia in the EU transport network TEN-T, introduction of railways instead of roads, which would ensure reduction of air, water and soil pollution, speed up the process of container transport and compliance with regulatory requirements, and most importantly would increase the capacity of the seaport, relieve seaport of congestion and ensure the flow of goods more evenly and efficiently. On the example of the Rijeka Seaport, it can be concluded from all research results that there is a very justified and proven need for the Rijeka Seaport to establish a dry port, and given the lack of alternative solutions, it may be the only solution. Research has shown that the optimal location is to establish a dry port in Zagreb.

\section{REFERENCES / Literatura}

[1] Jeevan, J., Salleh, N. H. M., Loke, K. B., Saharuddin, A. H. (2017). "Preparation of Dry Ports for a Competitive Environment in the Container Seaport System: A Process Benchmarking Approach". International Journal of e-Navigation and Maritime Economy, Vol. 7, pp. 19-33. ISSN: 2405-5352. https://doi. org/10.1016/j.enavi.2017.06.003

[2] Nguyen, L. C., Notteboom, T. (2016). "A Multi-Criteria Approach to Dry Port Location in Developing Economies with Application to Vietnam". The Asian Journal of Shipping and Logistics, Vol. 32, No. 1, pp. 23-32. ISSN: 2092-5212. https://doi.org/10.1016/j.ajsl.2016.03.003

[3] Roso, V., Lumsden, K. (2010). "A Review of Dry Ports". Maritime Economics \& Logistics, Vol. 12, No. 2, pp. 196-213. ISSN: 1479-2931. https://doi.org/10.1057/ mel.2010.5

[4] Oláh, J., Nestler, S., Nobel, T., Harangi-Rákos, M., Popp, J. (2018). “Development of Dry Ports in Europe". International Journal of Applied Management Science, Vol. 10, No. 4, pp. 269-289. ISSN: 1755-8913. https://doi.org/10.1504/ ijams.2018.095330

[5] Chen, J., Fei, Y., Zhang, F., Jing, C. (2018). "Evaluating Correlations between a Seaport and Its Dry Ports: Case Study of Xiamen Port in China". Discrete Dynamics in Nature and Society, Vol. 2018, No. 3, pp. 1-16. ISSN: 1026-0226. https://doi.org/10.1155/2018/6831302
[6] Abbasi, M., Pishvaee, M. S. (2018). "A Two-Stage GIS-Based Optimization Model for the Dry Port Location Problem: A Case Study of Iran". Journal of Industrial and Systems Engineering, Vol. 11, No. 1, pp. 50-73. ISSN: 1735-8272.

[7] Feng, X., Zhang, Y., Li, Y., Wang, W. (2013). "A Location-Allocation Model for Seaport-Dry Port System Optimization". Discrete Dynamics in Nature and Society, Vol. 2013, No. 4, pp. 1-9. ISSN: 1026-0226. https://doi. org/10.1155/2013/309585

[8] Mlinarić, T. J., Rogić, K., Rožić, T. (2011). “Methodology for Determining Dry Port System Transport Network - Case Study Port of Rijeka - Zagreb". DAAAM International Scientific Book, Vol. 10, pp. 133-146.https://doi.org/10.2507/ daaam.scibook.2011.11

[9] Dragović, B., Tzannatos, E., Park, N. K. (2017). "Simulation Modelling in Ports and Container Terminals: Literature Overview and Analysis by Research Field". Application Area and Tool, Flexible Services and Manufacturing Journal, Vol. 29 No. 1, pp. 4-34. ISSN: 1936-6582. https://doi.org/10.1007/s10696-016-9239-5

[10] Black, J., Roso, V., Marušić, E., Brnjac, N. (2018). "Issues in Dry Port Location and Implementation in Metropolitan Areas: The Case of Sydney, Australia". Transactions on Maritime Science, Vol. 7, No. 1, pp. 41-50. ISSN: 1848-3305. https://doi.org/10.7225/toms.v07.n01.004

[11] Woxenius, J., Roso, V., Lumsden, K. (2009). “The Dry Port Concept: Connecting Seaports with the Hinterland". Journal of Transport Geography, Vol. 17, No. 5 , pp. 338-345. ISSN: 0966-6923. https://doi.org/10.1016/j.jtrangeo.2008.10.008

[12] Kos, S., Brčić, D., Karmelić, J. (2010). “Structural Analysis of Croatian Container Seaports". Scientific Journal of Maritime Research, Vol. 24, No. 2, pp. 189-209. ISSN: 1332-0718.

[13] Barić, S., Devčić, I., Valenčić, M. (2008). “Analiza kontejnerskog prometa Luke Rijeka u usporedbi s konkurentskim lukama Kopar i Trst". Pomorski zbornik, Vol. 45, No. 1, pp. 165-179. ISSN: 0554-6397.

[14] Tomašević, M., Jadrijević, N., Dundović, Č. (2011). "The Analysis of the Container Traffic Movement in the Port of Rijeka Compared to the Container Traffic in the Port of Koper". Scientific Journal of Maritime Research, Vol. 25, No. 2, pp. 469-485. ISSN: 1332-0718. DOI: 10.31217/p.

[15] Kolanović, I., Grgas-Oštro, A., Dundović, K. (2015). "Ocjena i tendencije razvitka prekrcajnih kapaciteta kontejnerskih terminala luka Rijeka, Ploče i Kopar". Zbornik Veleučilišta u Rijeci, Vol. 3, No. 1, pp. 221-234. ISSN: 1848-1299. DOI: $10.31784 / z v r$.

[16] Dundović, Č., Plazibat, V. (2011). "Port and Traffic Infrastructure in the Republic of Croatia". Scientific Journal of Maritime Research, Vol. 25, No. 1, pp. 209-222. ISSN: 1332-0718.

[17] Zelenika, R., Mrvčić, A., Pavlić Skender, H. (2011). “Analiza i ocjena stupnja uspješnosti u poslovanju teretnih morskih luka u RH". NAŠE MORE / OUR SEA, Vol. 58, No. 1-2, pp. 9-21. ISSN: 0469-6255.

[18] Zenzerović, Z., Vilke, S., Jurjević, M. (2011). "Queuing Theory in Function of Planning the Capacity of the Container Terminal in Port of Rijeka". Scientific Journal of Maritime Research, Vol. 25, No. 1, pp. 45-69. ISSN: 1332-0718.

[19] Srđević, B., Srđević, Z., Zoranović, T. (2002). "PROMETHEE, TOPSIS i CP u višekriterijumskom odlučivanju u poljoprivredi". Letopis naučnih radova, Vol. 26, No. 1, pp. 5-23. ISSN: 0546-8264. https://doi.org/10.5937/Inrpfns 1401144 z

[20] Karleuša, B., Beraković, B., Ožanić, N. (2005). "Primjena ELECTRE TRI metode na izbor varijante navodnjavanja". Građevinar, Vol. 57, No. 1, pp. 21-28. ISSN: 0350-2465.

[21] Deluka-Tibljaš, A., Karleuša, B., Dragičević, N. (2013). "Pregled primjene metoda višekriterijske analize pri donošenju odluka o prometnoj infrastrukturi". Građevinar, Vol. 65, No. 7, pp. 619-631. ISSN: 0350-2465. https:// doi.org/10.14256/jce.850.2013

[22] Brockwell, P. J., Davis, R. A. (2016). Introduction to Time Series and Forecasting Switzerland: Springer International Publishing. ISSN: 1431-875X.

[23] Hunjak, T. (1997). "Mathematical foundations of the methods for multicriterial decision making". Mathematical Communications, Vol. 2, pp. 161-169. ISSN: 1331-0623.

[24] Izvješća o obavljenoj reviziji konsolidiranih financijskih izvještaja za razdoblje 1993.-2019., Luka Rijeka, Rijeka. https://lukarijeka.hr/financijska-izvjesca/ [accessed 2/5/2020]

[25] Seaport Rijeka Official Website. https://lukarijeka.hr/ [accessed 2/5/2020]

[26] Lovrić, I., Bartulović, D., Viduka, M., Steiner, S. (2020). "Simulation Analysis of Seaport Rijeka Operations with Established Dry Port". Scientific Journal of Maritime Research, Vol. 34, No. 1, pp. 129-145. ISSN: 1332-0718. https://doi. org/10.31217/p.34.1.15 